\title{
Collective Action and the Mobilization of Institutions
}

\author{
David Lowery \\ University of North Carolina at Chapel Hill \\ Virginia Gray \\ University of North Carolina at Chapel Hill \\ Jennifer Anderson \\ University of North Carolina at Chapel Hill \\ Adam J. Newmark \\ Wake Forest University
}

\begin{abstract}
Bias in the composition of interest communities is often explained by reference to variations in the collective action constraint facing voluntary and nonvoluntary organizations. But with the exception of literature on PAC formation, studies of direct institutional mobilization are rare. More often than not, their mobilization advantages vis-à-vis problems of collective action are simply assumed. This paper fills this gap by testing the collective action hypothesis on direct institutional mobilization. We argue that the PAC studies are flawed as tests of this hypothesis; they study the wrong mode of political activity and use selective samples and limited research designs. We develop a new test using state data on seven types of institutions to solve these problems. We also compare the collective action problem facing institutions to the related problems facing voluntary organizations. We find strong evidence of collective action problems in institutional mobilization, problems that make interest populations of nonvoluntary and voluntary organizations appear far more similar than commonly thought.
\end{abstract}

\begin{abstract}
T he literature on organized interests has long noted that interest systems are often biased in their composition. Using a common measure of bias of the interest system by examining the distribution of participants minimally active in various stages of the policy process, a number of scholars have noted that the distribution of interests before government reflects only poorly the distribution of interests in society (Baumgartner and Leech 2001; Berry 1999, 20; Caldeira and Wright 1990; Golden 1998; Salisbury 1984; Schattschneider 1960; Schlozman 1984; Schlozman and Tierney 1986; Walker 1991, 59). While venues vary, voluntary organizations - associations of institutions and membership groups-are more often than not a minority among organized interests lobbying government. And their minority status has increased over recent decades. For example, the proportion of the organized interests registered to lobby state governments has
\end{abstract}

THE JOURNAL OF POLITICS, Vol. 66, No. 3, August 2004, Pp. 684-705

(C) 2004 Southern Political Science Association 
increased from $39.55 \%$ in 1980 to $49.02 \%$ in 1990 and nearly $57.81 \%$ in 1997 (Gray and Lowery 2001a).

There is great controversy over whether and under what conditions bias in the composition of the interest community biases policy outcomes (Denzau and Munger 1986; Lowery and Gray 2001; Salisbury 1990, 228; Schattschneider 1960, 35; Smith 2000). While this is an important question, it is not one we address here. Rather, we consider an infrequently examined assumption many scholars make about the source or cause of bias in the composition of interest communities. Many observers account for the dominance of firms, traditional economic interests, and institutions via reference to Olson's (1963, 141-48) analysis of collective action. Groups with large stakes have greater incentives and fewer costs in overcoming barriers to organization than larger latent groups with smaller stakes. Schlozman and Tierney $(1986,130)$ were especially explicit about explaining bias in lobbying presence by reference to variations in free riding, and their interpretation has become standard in both graduate and undergraduate textbooks on interest representation (Baumgartner and Leech 1998, 115; Nownes 2001, 52-54). We examine this assumption by testing Olson's collective action hypothesis on direct lobbying by institutions in the American states. Our test has important implications for the study of interest communities. Evidence that collective action issues bear more heavily on institutional mobilization than is commonly thought, combined with the now substantial body of work that free riding does not solely determine the fate of voluntary organizations, would not, however, invalidate Olson's analysis. Indeed, it would extend his work by suggesting that the collective action problem has a wider application than commonly appreciated. Rather, the key implication of finding that institutional mobilization is also severely constrained by free riding concerns our understanding of bias in interest communities. Simply put, we would need to develop new theories of bias that go beyond simple assumptions about variations in the severity of collective action problems across different types of organized interests. We first discuss the common assumption that collective action problems bear unequally across institutions and voluntary organizations and identify a number of problems in the limited evidence now available on institutional mobilization. We then develop a new test sidestepping these problems using comparative state data on seven types of institutions. We also provide a more general, albeit tentative, comparison of the severity of the collective action problems facing institutions and voluntary organizations.

\section{Collective Action, Institutions, and PACs}

The broad consensus about the role of collective action issues in accounting for bias in the composition of interest communities is puzzling in two ways. First, assessments of the severity of collective action problems for voluntary organizations have been tempered over the last 30 years. Free riding has been found to be less common than Olson had expected in both laboratory settings (Marwell 
and Ames 1979, 1980) and the real world of organized interests (Berry 1999). Some scholars explain this gap by discounting the sharp distinction he makes between collective and selective benefits (Clark and Wilson 1961; Salisbury 1969). Others discuss how cognitive biases (Hansen 1985; Moe 1980) and organizational contexts (Verba, Schlozman, and Brady 1995) promote mobilization. And still others highlight the importance of subsidies by patrons, entrepreneurs, and other organizations (Rosenstone and Hansen 1993; Salisbury 1969; Walker 1991). While few scholars fully reject Olson's analysis as applied to the mobilization of voluntary organizations, the accumulation of addenda has reached a point where many now ask, as Baumgartner and Leech have phrased it, "whether the problems discussed by Olson may have been given more prominence in the interest-group literature than they deserve" $(1998,75)$,

The second part of the puzzle concerns the mobilization of institutions - organizations without members. That is, bias in the interest system is thought to derive from the relative differences in propensities to mobilize between voluntary and nonvoluntary organizations. Yet, with the exception of the literature on PACs, examined more fully below, studies of direct lobbying by institutions are extraordinarily rare. More often than not, the mobilization advantages of institutions visà-vis issues of collective action are simply assumed. The lack of attention to direct institutional mobilization likely arises, as suggested by Baumgartner and Leech $(1998,67)$, from Olson's emphasis on the incentives of individuals in The Logic of Collective Action. But he well recognized that institutions also face incentives to free riding. That is, participation rates in direct lobbying by institutions may be lower in states (or industries) with many firms than in states (or industries) with few. ${ }^{1}$ If so, then biases in the composition of interest communities cannot be readily explained by simply claiming that some kinds of organizations are subject to free-riding problems while others are not. Instead, we need to compare the severity of the collective action problem across different types of interest organizations.

Whether or not the rate of direct lobbying by institutions varies with the size of institutional populations depends, according to Olson's logic, on what they lobby for. If, as Salisbury (1984) has suggested, institutions lobby primarily for selective benefits, rates of participation in direct lobbying should not vary with the number of institutions in a state or an industry. But if, as suggested by Grier, Munger, and Roberts $(1991,728)$, institutions typically seek collective goods that benefit a whole industry, then we should observe higher rates of free riding in populations with more institutions. It is, of course, almost certainly true that institutions lobby for both collective and selective benefits. So it is the relative balance of these two lobbying objectives that determines the severity of the collective action problem institutions face. To date, these competing hypotheses have been tested almost exclusively in terms of the founding of national-level PACs by busi-

\footnotetext{
${ }^{1}$ A second type of collective action issue bearing on insitutions not studied here concerns the rate of participation of institutions in trade associations, a type of voluntary organization.
} 
ness firms. Indeed, the collective action issue is central to the PAC literature. As Grier, Munger, and Roberts noted in their analysis of PAC sponsorship, "Mancur Olson's Logic of Collective Action provides the theoretical cornerstone for most discussions of corporate political participation. At the heart of Olson's theory is the rational calculus of individual agents leading to a decision to join in lobbying government or not" $(1991,728)$.

Unfortunately, the PAC literature provides mixed evidence on the importance of collective action problems for institutions. Controlling for a variety of variables that might influence mobilization rates (including the degree to which industries are regulated, firm size, profitability, and a number of other variables), some scholars have found that the number of firms in an industry is negatively related to PAC sponsorship (Andres 1985; Masters and Keim 1985; McKeown 1994). This finding, of course, is consistent with the notion that some portion of what institutions lobby for includes collective goods. Other scholars, however, have found that the rate of free riding by failure to sponsor a PAC does not increase with the number of firms in an industry (Boies 1989; Grier, Munger, and Roberts 1991, 1994; Hart 2001; Humphries 1991). Given Olson's analysis, this finding is consistent with the notion that institutions lobby for selective goods. Still others find more mixed results indicative of some, if limited, free riding (Mitchell, Hansen, and Jepsen 1997). So, while Olson's hypothesis is central to the PAC literature, it does not provide a definitive answer on the importance of free riding for institutions.

But even if the PAC literature agreed on the importance of free riding to institutions, studying PACs would still provide a poor test of the impact of collective action issues on rates of institutional lobbying. ${ }^{2}$ First, while a valid indicator of campaign finance activity, PAC sponsorship is a poor measure of engaging in politics (Hansen and Mitchell 2000, 896). PACs are but one tool for gaining access to the political process and not, therefore, evidence of engagement with the political process per se (Hansen and Mitchell 2000, 892; Herndon 1982; Matasar 1986, 52; Sabato 1984; Sorauf 1984, 73; Wright 1989, 1990). Further, PAC use is not widespread in comparison to other modes of political engagement (Gais 1996, 78). If PAC formation is a minor means of political activity by organized interests already committed to seeking political influence, they constitute a singularly inappropriate venue for studying collective action issues. The collective action problem should bear on the decision to engage in any political activity, not the means or intensity by which that engagement is expressed (Gray and Lowery 1997). We need to study the broadest, most basic form of political participation by institutions - lobbying - to assess validly the severity of the collective action problems they face. ${ }^{3}$

\footnotetext{
${ }^{2}$ The PAC studies tell us a great deal about the campaign finance activity of large firms. Thus, they make important contributions to knowledge about substantively important issues. We only suggest that they are singularly inappropropriate as tests of the collective action hypothesis.

${ }^{3}$ Hansen and Mitchell's (2000) study of Fortune 500 firms provides one of the few tests of the collection action hypothesis at the national level focused on lobbying. But given the lack of federal
} 
Second, although not inherent, most PAC studies examine the campaign finance activities of only large firms-Fortune 500 (Andres 1985; Boies 1989; Hansen and Mitchell 2000; Mitchell, Hansen, and Jepsen 1997), Fortune 100 (Humphries 1991; Masters and Keim 1985) or even smaller subsets of firms (Hart 2001; McKeown 1994). These truncated samples are troubling given that the absolute size of the expected returns on political activity are likely to be larger for larger firms, and large firms are more visible politically. Both factors surely enhance incentives to overcome free riding. Thus, attention to only large firms surely minimizes variance on traits that likely bear directly on propensities to free ride. What is needed is attention to the full population of institutions that might engage in political activity.

Third, PAC studies employ a single interest population, inter-industry research design. That is, they typically examine PAC sponsorship across industries/firms within a single population of industries/firms. This strategy might be effective if we could plausibly account for the many differences among industries/firms that shape their proclivities to engage in political activity. Despite some heroic efforts, controlling for these differences is difficult given complex variations in the economies of scale of political organization, the heterogeneity of interests, and range of policy interests across industrial sectors. Thus, PAC models are likely to be underspecified. A more tractable research design would entail comparing within given industries across populations in which the numbers of firms that might lobby vary, thereby controlling for a variety of forces operative across industries.

\section{Modeling the Collective Action Problem}

In contrast to most prior studies, we examine direct lobbying by institutions rather than the more limited behavior of sponsoring a PAC. We examine lobbying behavior in the states, which provide both substantial variance in the size of the full institutional populations that might lobby and valid lobby registration data. We will see below that shifting attention to states has important advantages. But it has costs as well. There were only 4,000 national PACs in 1997, and federal PAC registration data provides substantial information on their sponsors. In contrast, 34,680 organizations registered to lobby in the states in 1997, and state registration data is often skimpy, sometimes providing no more than the name of the organization. Given the sheer number of cases and the paucity of information about specific firms, state registration data cannot be coded in the same detail as federal PACs. So, we must employ more highly aggregated categories of industries than is common in the PAC literature. Higher levels of aggregation are also

lobbying data, they rely on older measures of doubtful validity (Baumgartner and Leech 2001) - the number of Washington representatives and hearing appearances. Further, neither really speaks to the core behavior examined by the collective action hypothesis - the decision to engage in any political activity. 
needed because states are the unit of analysis. That is, industries had to be aggregated at a sufficiently high level that an adequate number of direct institutional lobby registrations could be observed in each state for valid analysis. For example, manufacturing firms comprise our largest sector with a total of 3,088 registrations in 1997, an average of only 61.76 per state. If these 61.76 registrations were coded any more finely, valid analysis would be very difficult. Given these problems, we analyze participation in direct lobbying by all of the institutions in the following seven economic sectors, with their total number of lobby registrations and the mean number of registrations per state listed in brackets: (1) agricultural services, forestry, and fishing [280, 5.60], (2) natural resources [908, 18.16], (3) construction [323, 6.46], (4) manufacturing [3,088, 61.76], (5) transportation, utilities, and communication (T-U-C) [2,423 48.46], (6) finance, insurance, and real estate (F-I-RE) [1,664, 33.28], and (7) local government [2,277, 45.54]. The seven sectors were selected because they allow us to readily match prior counts of lobby registrations by economic sectors with data on firm populations in states. The seven sectors accounted for 16,476 lobby registrations by organizations in $1997,47.82 \%$ of the total. The proportions of institutions (58.63), associations (21.27), and membership groups (20.01) in our sample sectors are comparable to the full population.

The dependent variable, participation rate, is measured by the proportion of firms or local governments within a sector in each state registered to lobby in 1997. The lobby registration data were gathered by mail or Web page from state agencies responsible for their maintenance. ${ }^{4}$ After purging the lists of state agencies in those states requiring their registrations, organizations registered to lobby — rather than the lobbyist — were coded on several dimensions, including

\footnotetext{
${ }^{4}$ The coding of lobby registrations by economic sector was based on the Bureau of the Census coding of economic sectors. Examples of the organizations with in sector are as follows: natural resources/commercial resource development (oil and mining companies and associations, miners associations, drilling companies, and oil, water, and environmental-geotechnical organizations); construction/housing (construction firms, contractors associations, landlord associations, tenant unions, appropriate unions, and paving companies); Finance-Insurance-Real Estate (banks, credit unions, banking associations, finance agencies, investment and securities companies, appropriate economic development institutions, mortgage brokers, credit bureaus, realtors, credit card and check cashing organizations, student loan agencies, estate/trust managers, and bond organizations); agriculture, forestry, and fisheries (farm organizations, food processors, timber companies and associations, loggers associations, appropriate unions, corporate farms, sea food/fishing industry); intergovernmental relations and local governments (local governments and associations, appropriate unions, public employee and retiree groups, government boards, municipal associations, and port authorities, police and fire associations, education associations, school districts); manufacturing (companies producing goods, manufacturing associations); transportation, utilities, and communication (transportation companies, trucking companies and associations, transit authorities and advocates, airline, bus, railroads, and steamship companies, related unions, electric companies, phone and water companies, utility boards, TV and radio stations and associations, newspapers, broadcaster and journalist associations, publishing companies, and entertainment companies, and internet providers). Of the matches between the firm and lobby registration data, the most problematic match arises from exclusion from the local government count of a few public utilities included in the T-U-C count.
} 
organizational type (institution, membership group, or association) and interest content (27 categories of substantive interests), using directories of organizations, associations, and groups and the Web pages of individual organizations. A second coder then examined the coding assignments with discrepancies resolved via discussion between the two coders. The data on number of firms in each state in 1997 were obtained from the U.S. Census Bureau's Web site. The Census Bureau (http://www.census.gov/csd/susb/defterm.html) reports both numbers of firms and establishments by states. Because they are so highly correlated $(r>.99)$, we employ number of firms. Data on the number of local governments-including counties, municipalities, townships, schools districts, and special districts-in 1997 were obtained from the Statistical Abstract of the United States (U.S. Department of Commerce 2000, 299).

Two problems may undermine the validity of our participation measure. First, state lobby laws vary in terms of registration and reporting requirements and the stringency of their sanctions. If these reflect variations in the relative costs of lobbying across the states, then they may well account for variations in free riding. In states with minimal requirements, institutions may be more inclined to routinely register to lobby. But while lobby laws vary somewhat, registration costs are not high in any state. More to the point, previous research using two standard measures of regulatory stringency indicates that these variations have little impact on numbers of lobby registrations (Lowery and Gray 1994, 1997) or the diversity (Gray and Lowery 1998) of state interest communities. A second problem concerns the potential for some interest organizations to register in many states. If so, the numerator and denominator in the participation measure may tap somewhat different populations. This potential confound, however, does not seem to be too severe empirically. Of the 21,089 distinct organizations registered to lobby in the states in 1997, 18,267 (86.62\%) were registered in but a single state, presumably the state in which they do business (Wolak et al. 2002). Even among the 2,831 organizations with multistate registrations, the mode was two, the median three, and the mean only 5.73 registrations. Thus, the participation measure is not seriously distorted by out-of-state registrations. ${ }^{5}$

We have already noted some of the costs of using state rather than the firm or industry data typically used in the PAC literature. But our use of state data offers one major advantage beyond simply looking at the full population of institutions that might engage in lobbying, rather than only large firms. Because we are using a multipopulation, within-industry research design, we have less need to control for a number of variables essential to the specifications of the PAC literature. By comparing participation rates within industries but across states, most of the variables in the PAC studies used to control for differences across industries are con-

\footnotetext{
${ }^{5}$ To further control for multistate registrations, models not reported here included Wolak et al.'s (2002) measure of the degree to which state lobbying populations were dominated by within-state registrations. When included, the localism index produced an incorrectly signed estimate in all cases but one, none were significant, and little else in the results was influenced.
} 
stants in our analyses. We do not, for example, need to account for variations in the heterogeneity of interests or economies of scale in representation across industries. And it is unlikely the variations across the states in the regulation of a given industry, like local government or financial services, are as large as variations in regulations across industries.

Still, we introduce a number of controls to account for plausible differences across the states that might influence participation rates. First, we control for the severity of the economic problems in each sector. Truman's disturbance theory of mobilization (1951) and Lowery and Gray's (1995) ESA model of interest system density suggest that organizations are more likely to lobby when threatened. Following Plotke's (1992) argument that business mobilization is associated with falling profits, we measure such threats with the absolute growth in current dollar gross state product (GSP, in millions of dollars) derived from the industry from 1992 to 1997 . If sector GSP growth in a given state is higher than in other states, its member firms should be less inclined to lobby.

Second, we control for the level of party competition in a state. Lowery and Gray (1995) suggest that organizations are more likely to mobilize when the outparty is more likely to become the in-party, thereby threatening old benefits and creating opportunities for new benefits. State party competition is measured by a folded Ranney index for the 1995-98 period.

Third, we control for the overall size of the interest community exclusive of the number of organizations in a given industrial sector. Lowery and Gray (1998a) and Gray and Lowery (2001a) suggest that institutions are more likely to lobby when interest systems are crowded. Under such conditions, trade associations have incentives to inflate their presence by encouraging their member firms to lobby on their own in support of the association so as to increase the frequency and volume of their messages.

Fourth, we control for the number of associations representing the industry registered to lobby state legislatures. Large states are more likely to support a greater number of finely targeted associations than are smaller states. Under such conditions, firms may believe that the associations to which they belong adequately represent their interests, depressing the likelihood that they will lobby on their own. In states with fewer associations, however, firms may believe that they have little choice but to lobby directly. Sector associations (voluntary organizations with institutions as members) were readily distinguished from membership groups (voluntary organizations with individuals as members) within most of the economic sectors. Indeed, most have few membership organizations, and these are typically unions or professional associations. But this distinction was less clear for the agricultural sector where membership groups like Georgia's Cattlemen's Association function much like trade associations in other sectors. In the agriculture case, therefore, membership groups and associations are tallied in the variable measuring the number of trade associations in the sector. ${ }^{6}$

\footnotetext{
${ }^{6}$ Essentially the same results obtained using the standard coding for agricultural organizations.
} 
Finally, we control for the average size of firms within states. While finding quite mixed evidence on free riding, the PAC literature is nearly uniform in finding that firm size matters. Firms with more assets, sales, and/or employees are more likely to sponsor PACs. To some extent, we control for this factor with our within-industry design; firm size across the states within industries is more likely to be similar than across industries within states. But some states might still, on average, have larger firms than others. We control for average firm size with the ratio of 1997 sector GSP to its number of firms.

\section{Collective Action and Direct Institutional Lobbying}

We must first establish that the seven sectors reflect more than a single distribution of institutions. The sectors vary in size, with a 50-state average of only 453.82 natural resource firms in the smallest sector and an average of 13,280.12 construction firms in the largest. A more troubling concern would be if the same states always held the same relative position in terms of number of institutions, effectively collapsing our seven sectors into one. But while large states tend to have more of all types of institutions than smaller states, there is considerable variation in the rank order of the states across the sectors. Rank order correlations of the numbers of institutions in the sectors range from a high of only .451 for agricultural and manufacturing firms to a low of .012 for local governments and F-I-RE firms. Thus, the seven sectors provide relatively distinct contexts in which to test the collective action hypothesis.

Surprisingly, given alarm about the growing dominance of institutions, direct lobbying is rare at the firm level. The natural resource sector evidences the highest participation rate of $4.00 \%$; an average state's 453.82 natural resource firms generating an average 18.16 lobby registrations. Local government and TUC participation rates were somewhat lower: 2.60 and $1.04 \%$, respectively. Given the sizes of the two sectors, these participation rates generate in the average state, respectively, 45.54 and 48.46 lobby registrations. Manufacturing, F-I-RE, and agriculture participation are an order of magnitude lower ( $.87, .35$, and .24 , respectively), with average registrations of $61.76,33.28$, and 5.60, respectively. And construction firms participate the least; on average, less than .05 of a percent of these firms lobby. Given their great number, however, this still produces 5.60 registrations in the typical state. Thus, lobby participation rates are quite low for all seven sectors.

As a first cut in assessing the collective action hypothesis, we regressed participation rates as a power function on number of institutions for all seven sectors. The construction and agricultural models could not be estimated as power functions, however, given the presence of several cases with zero registrations. Instead, logarithmic functions were used for these models. ${ }^{7}$ The results presented

\footnotetext{
${ }^{7}$ The addition of a small constant (.001) to the dependent variables in order to use the same estimation technique across all seven sectors generated very similar results to the logarithmic models.
} 
FIGURE 1

Scattergram of Number of Manufacturing Firms and Firm Lobby Participation Rate

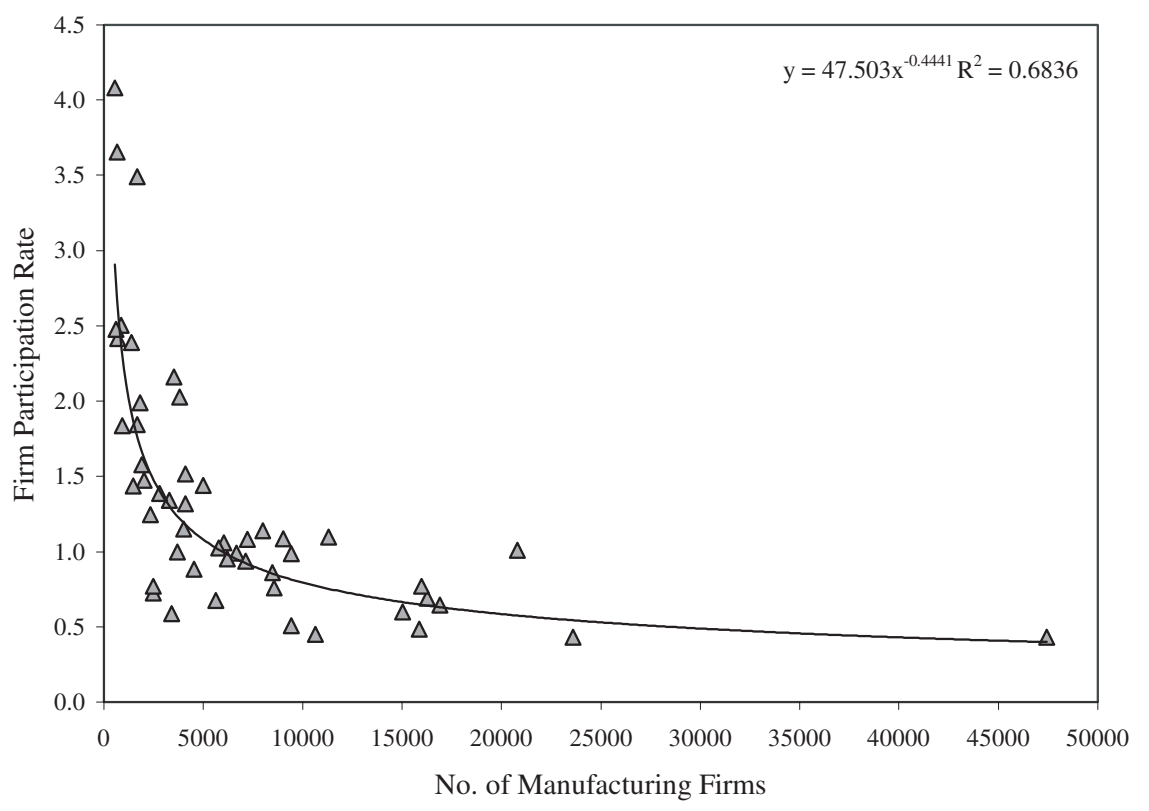

in Figures 1 though 7 provide strong support for the collective action hypothesis. That is, participation rates decline in six of seven cases, but at a declining rate, as the number of institutions in a given sector in a state increase. Still, the results vary. They are especially strong for the manufacturing $\left(\mathrm{R}^{2}=.684\right)$, natural resource (.671), and T-U-C (.600) sectors. Only the construction sector produced weak results $\left(\mathrm{R}^{2}=.062\right)$ and a nearly linear logarithmic function. This likely reflects the large number of truly tiny firms in the construction industry, an issue that may be addressed by our addition of controls.

The curvilinear relationships in the figures make two points. First, their steeply negative linear elements - where the bulk of states are - tell us that free riding is a serious problem for institutions. The decline in participation rates as institutional populations grow implies that much of what institutions lobby for concern collective benefits. But second, the curvilinear element reported for six of seven sectors at least suggests the possibility that selective benefits remain on the agendas of some institutions lobbying on their own. Even in large populations providing few incentives to pursue collective goods, some institutions remain in their state capitals seeking influence over public policy.

We cannot, of course, determine with these data what these institutions lobby for. They may include institutions committed to lobbying for collective goods 


\section{FIGURE 2}

Scattergram of Number of Construction Firms and Firm Lobby Participation Rate

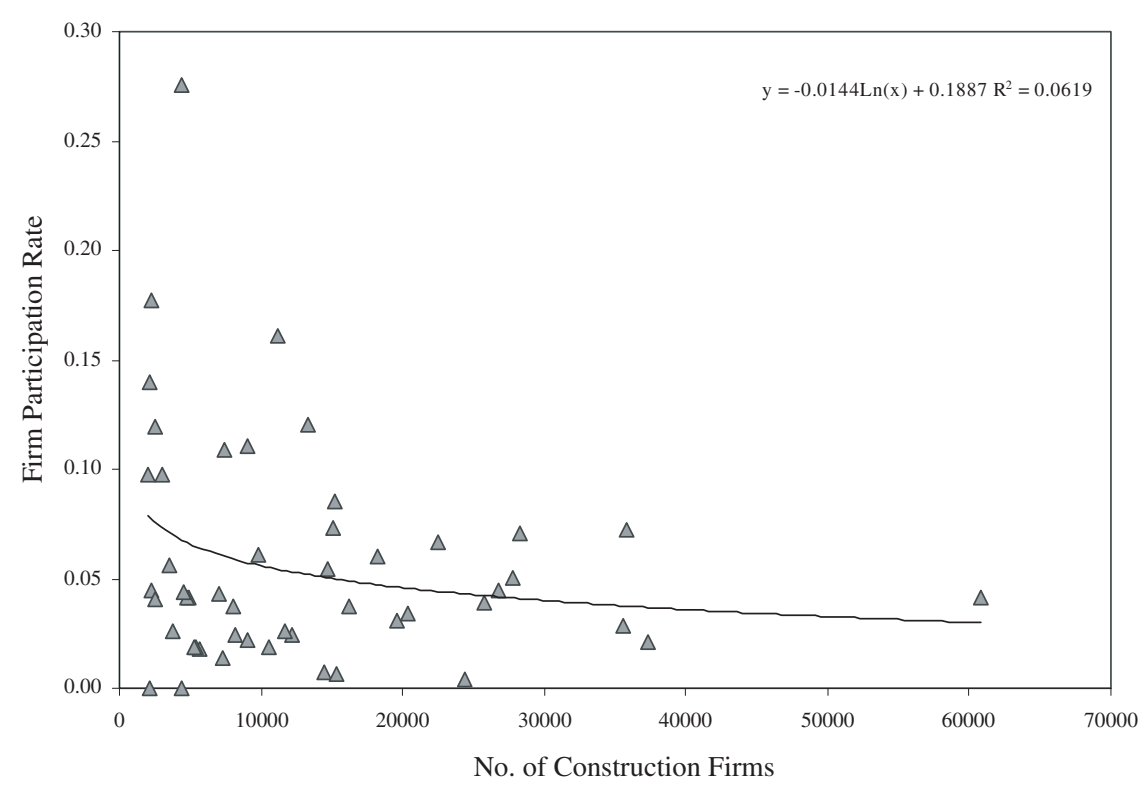

even in the face of incentives to free ride. Or, they may be very large firms for whom the marginal costs of lobbying for collective goods are small relative to their marginal share of the collective benefit. But we think it far more plausible that, given Olson's analysis of the decision to participate as a form of rational calculus, they seek selective benefits and cannot, therefore, afford to abandon the lobbying task. Indeed, Olson argued that collective benefits can take on many of the characteristics of selective benefits when one's share of the collective benefit becomes large. But even if selective or quasi-selective benefits justify their lobbying while others free ride, their efforts surely provide along the way some collective representation for their stay-at-home brethren. In very large populations, then, collective representation may be limited to that either provided by associations or generated by individual firms as a by-product of their pursuit of selective benefits.

Do these results survive the addition of control variables and use of a polynomial specification to unpack the linear and curvilinear components of the relationships? ${ }^{8}$ As seen in Table 1, the number of institutions variable generates

\footnotetext{
${ }^{8}$ Some may not like our proportional dependent variable. We also estimated the models with raw numbers of institutional registrations as a dependent variable. The results are similar in all important
} 
FIGURE 3

\section{Scattergram of Number of Agricultural Firms and Firm Lobby Participation Rate}

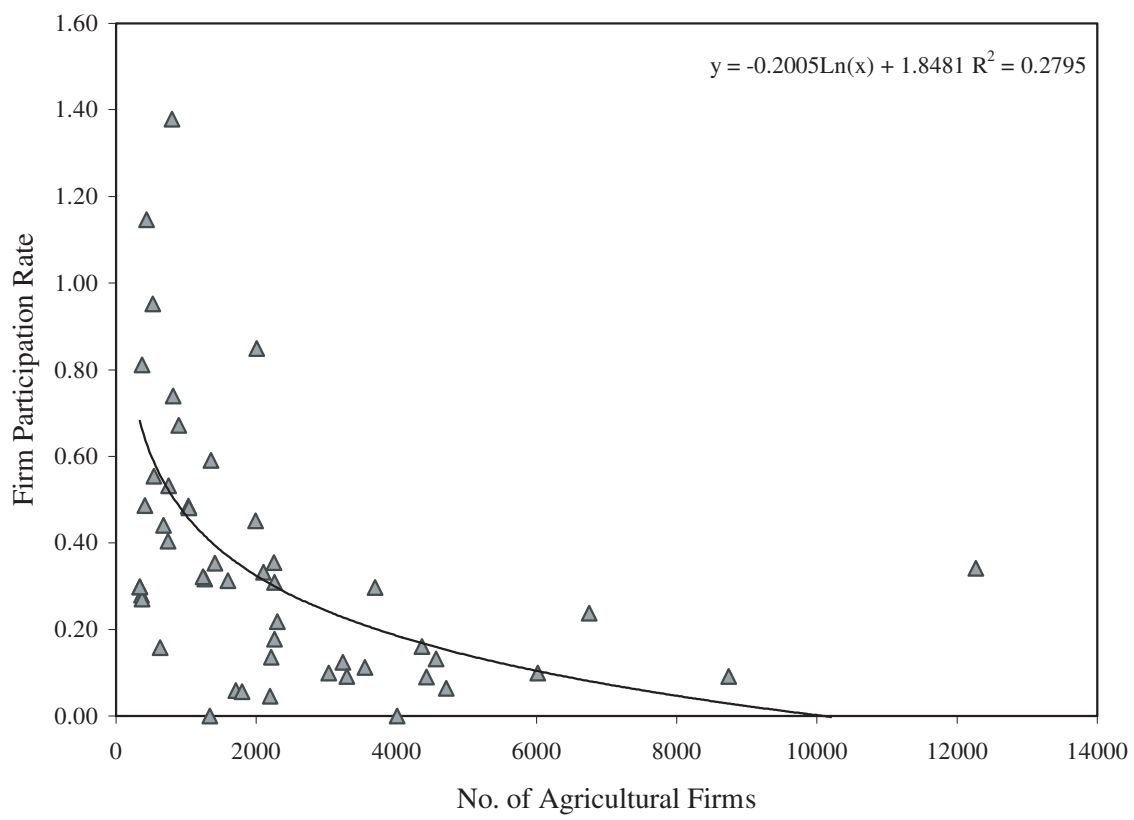

uniformly negative and significant estimates, indicating that participation rates decline as number of institutions grow. But the firm-squared term (divided by 100,000 for ease of presentation) generates uniformly positive coefficients, indicating that the decline in participation rates moderates as number of institutions increases. All of the estimates of the squared term are significant at the usual criterion levels except for the construction sector, although it too was discernible at the .10 level. Still, the construction sector results are now largely consistent with those of the other six sectors. This consistent pattern of results suggests that direct institutional lobbying - across a wide range of levels of participation - is highly conditioned by problems of free riding.

The control variables produced varied results. None of the estimates for change in GSP and party competition were significant. And only the F-I-RE sector's number of associations estimate was negative and significant, suggesting that the availability of more associations reduces direct lobbying. The results for the two

respects - the appropriate signs and significance of the estimates indicating a curvilinear registration response function to number of firms in each sector. In these models, however, it is far more difficult to sort out the independent impact of total registrations, since these are so strongly related to the raw numbers of registrations in any one sector. Thus, we prefer the specification presented here. 
FIGURE 4

Scattergram of Number of Natural Resource Firms and Firm Lobby Participation Rate

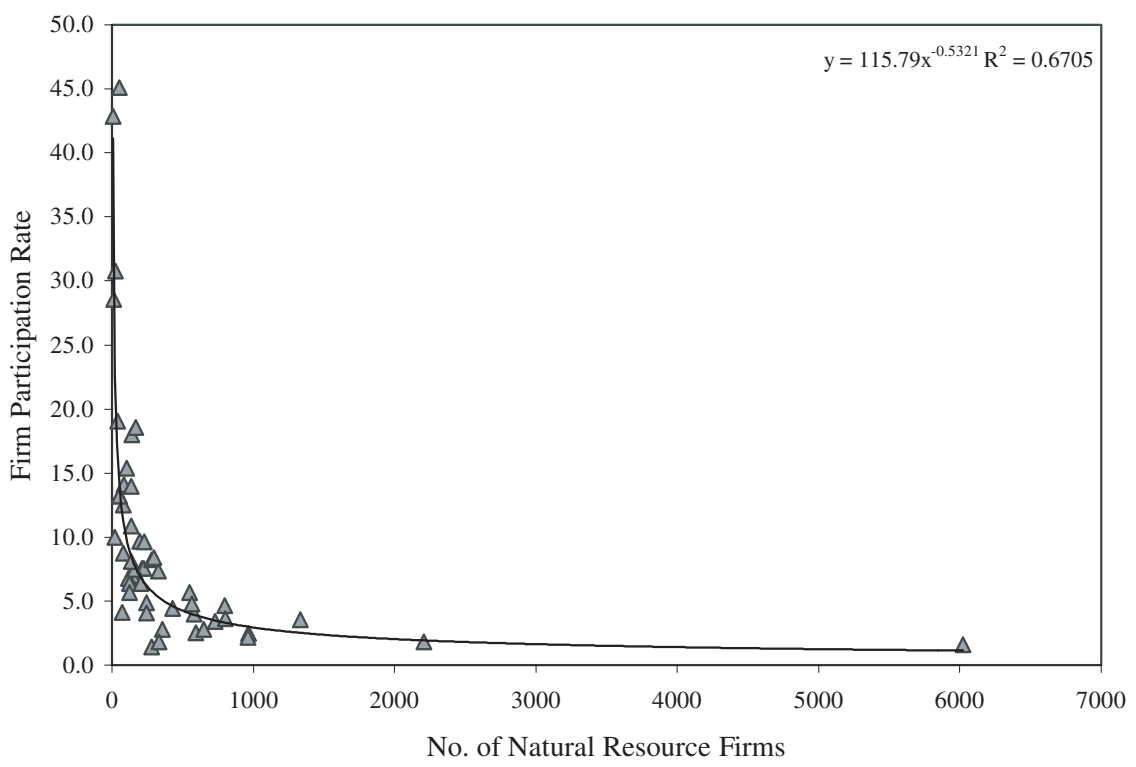

remaining controls are more noteworthy. Except for agriculture, the average firm size estimate was positive as expected, indicating that propensities to lobby increase with the average size of institutions within a sector within a state. The exception was not statistically discernible, however. And two of the correctly signed estimates - manufacturing and F-I-RE-were significant at only the .10 level. But two others - for construction and local government - were highly significant. While these sectors produced two of the weaker bivariate plots in Figure 1, their results in Table 1 provide stronger evidence of free riding. Thus, controlling for firm size sharpened the evidence in support of the collective action hypothesis. Last, number of nonsector registrations generated positive and significant estimates in the manufacturing, construction, T-U-C, and F-I-RE sectors.

\section{Comparing Institutions and Voluntary Organizations}

The results in Table 1 provide strong evidence that problems of free riding weigh heavily on direct lobbying by institutions. In this regard, then, they are not so very different from voluntary associations, either associations with institutions as members or membership groups with individuals as members. But how similar 
FIGURE 5

Scattergram of Number of T-U-C Firms and Firm Lobby Participation Rate

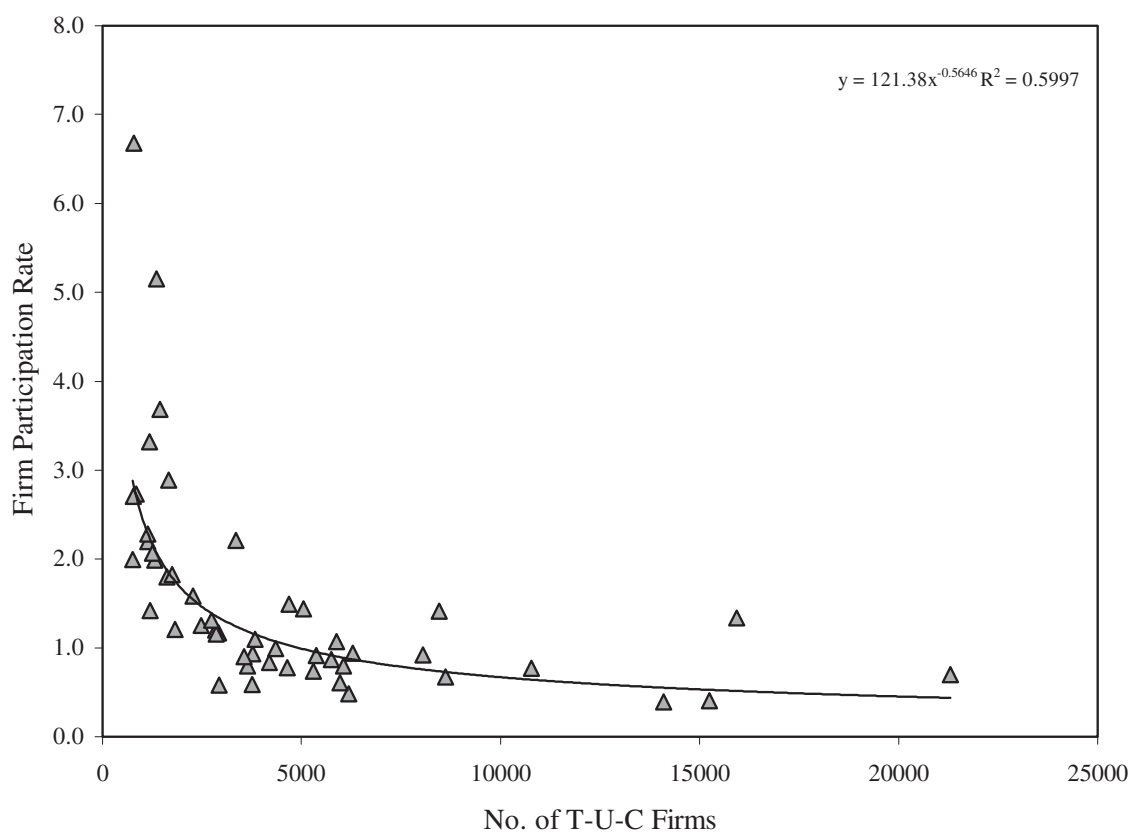

are they? This is a very difficult question to answer for two reasons. First, comparing all institutions with all membership groups and all associations requires a high level of aggregation, aggregation that will subsume many important differences across many types of organizations within each sector. Indeed, this is the very reason we have argued that a within-industry or sector, multiple population design is to be preferred over conventional PAC tests of the collective action hypothesis.

Second, the collective action problem bears differently on the lobby participation rates of voluntary organizations and direct lobbying by institutions. Participation rates in direct institutional lobbying are directly affected by free riding. As we have seen, free riding influences the proportion of institutions in a state willing to lobby. The impact of free riding on voluntary organizations entails, however, a two-step process. That is, free riding first influences the number of institutions willing to join trade associations or the number of individuals willing to join membership groups. The second step in this process concerns the organizationlevel impacts of this membership effect. If rates of joining are lower when there are many potential members, such as in larger states or in trades with many firms, 
FIGURE 6

Scattergram of Number of F-I-RE Firms and Firm Lobby Participation Rate

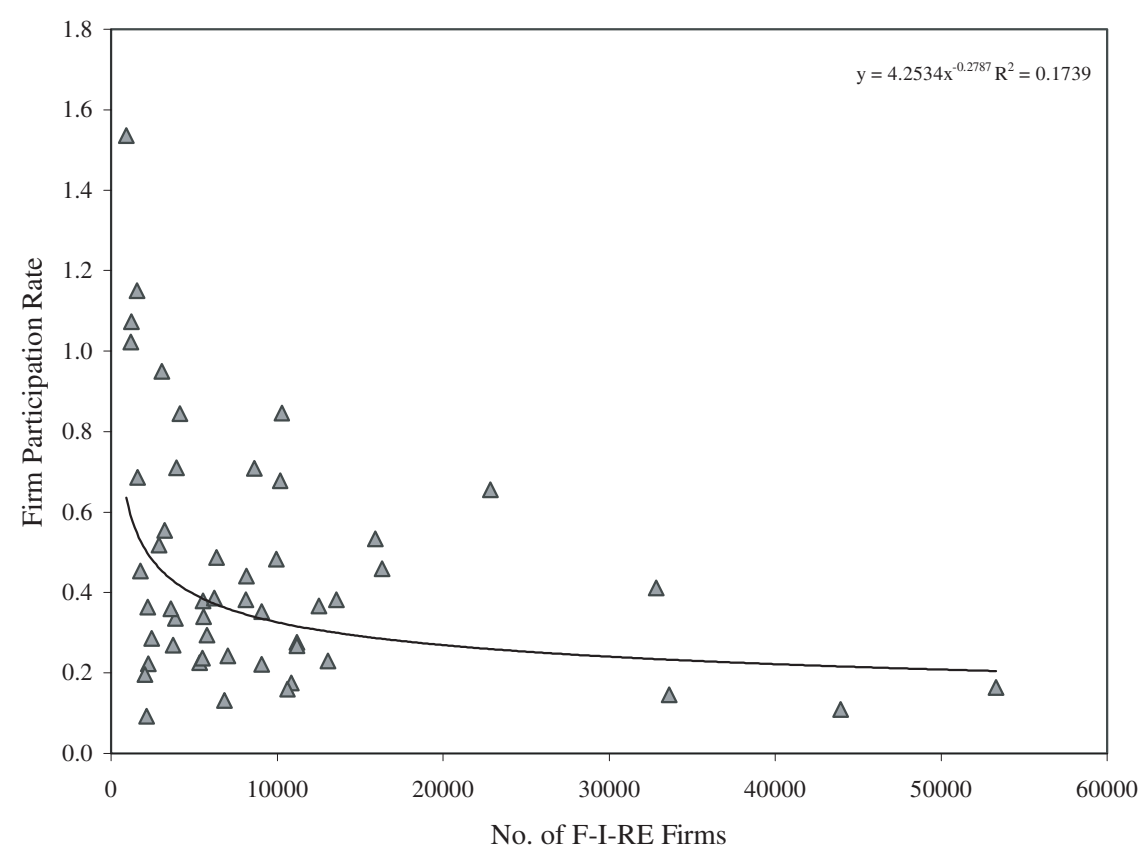

then it may be more difficult to mobilize or sustain interest organizations. For our data, this means that we should see lower rates of lobbying by voluntary organizations in larger states than in smaller states. So, any effort to contrast the impacts of free riding on the presence in lobbying communities of voluntary organizations and institutions lobbying on their own behalf necessarily entails something of an apples and oranges comparison. The impact of free riding on direct institutional lobbying is direct. For voluntary organizations, in contrast, it has a secondary impact by influencing organizational survival rates.

Still, the conventional explanation of bias in interest communities rests on precisely these kinds of comparisons. So, with our reservations in mind, we can provide a broad comparison by looking at the relationship between the global participation rates of institutions, associations, and membership groups in lobbying state legislatures. Making this comparison requires that we find a common measure of participation appropriate across all three types of organized interests comparable to our participation rate measure for firms. For the numerator, we use the total number of each type of organization registered to lobby in a state. The denominator in each case is state size, as measured by 1996 GSP. This measure 
FIGURE 7

\section{Scattergram of Number of Local Governments and Local Government Participation Rate}

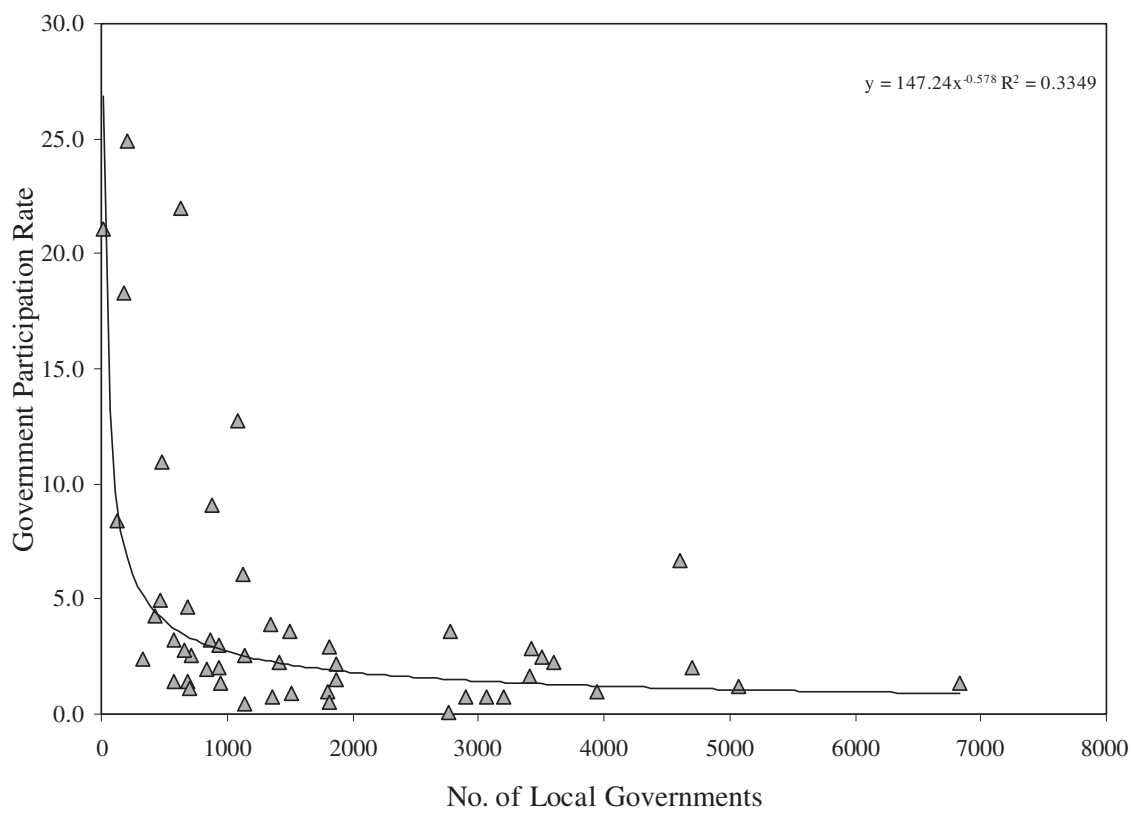

puts all three types of interest organizations on a common scale by specifying the rate at which a state produces interest organizations registered to lobby relative to the size of its economy. ${ }^{9}$

Figure 8 reports the results from regressing the three sets of participation scores for the states on the measure of state size. As seen in the top right of the figure, the capacity of state economies to produce the three types of organizations differs somewhat. But given our high level of aggregation and the likelihood that we are comparing apples and oranges, these differences are likely less important than the overall similarity of the three response curves. That is, the participation rates of institutions, associations, and membership groups all decline sharply, but then flatten, as states become larger. A given unit of GSP produces fewer interest organizations of all types as state economies increase in size. The key point to be drawn from this rough demonstration is that while collective action problems do seem to handicap direct lobbying by institutions as states become larger, it does not seem to either advantage or disadvantage them with respect to

\footnotetext{
${ }^{9} \mathrm{GSP}$ is a good surrogate indicator because number of institutions increases in a nearly linear manner with GSP for nearly all economic sectors (Lowery, Gray, and Fellowes 2002).
} 


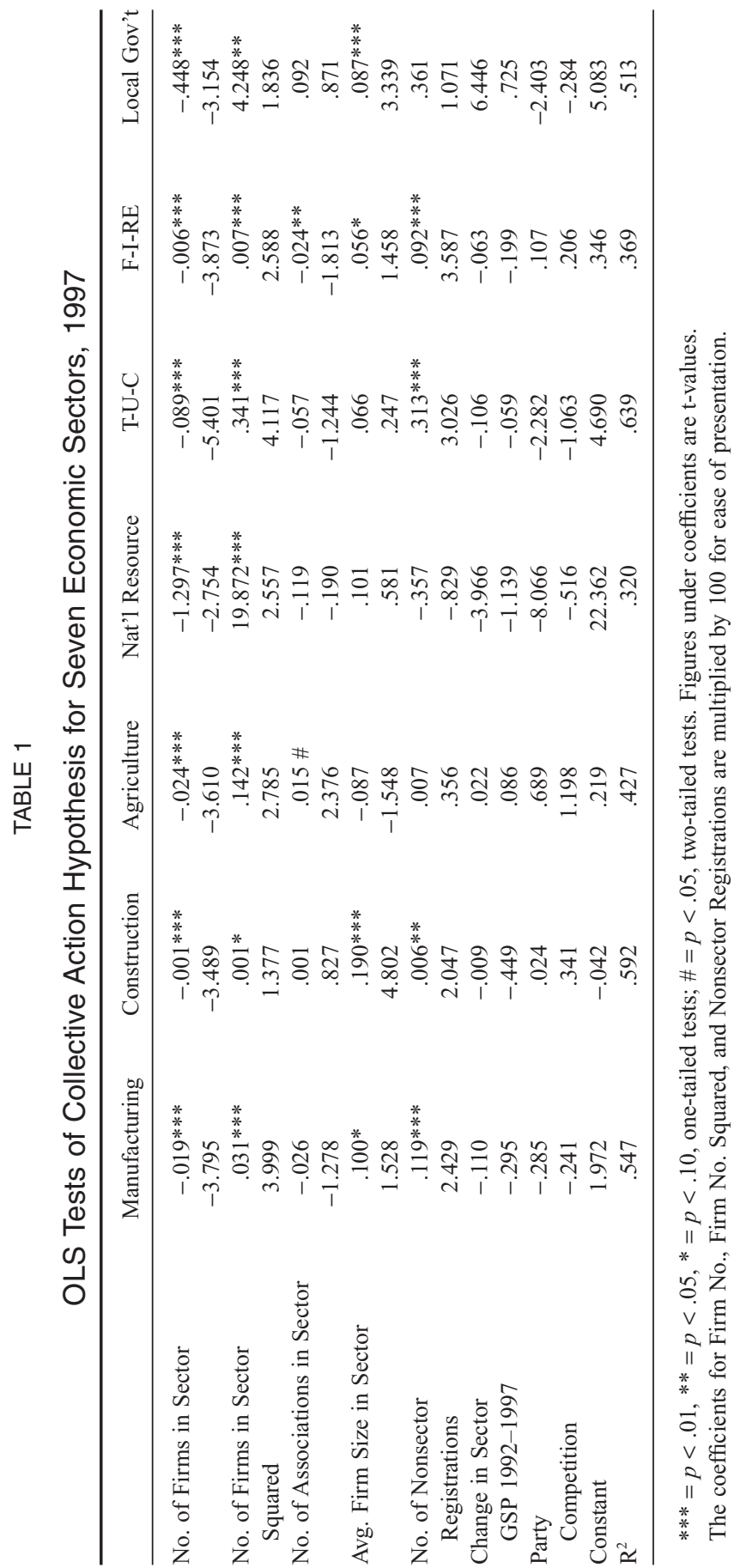


FIGURE 8 Power Function of Membership Group, Association, and Institution
1997 Participation Rates and 1996 GSP

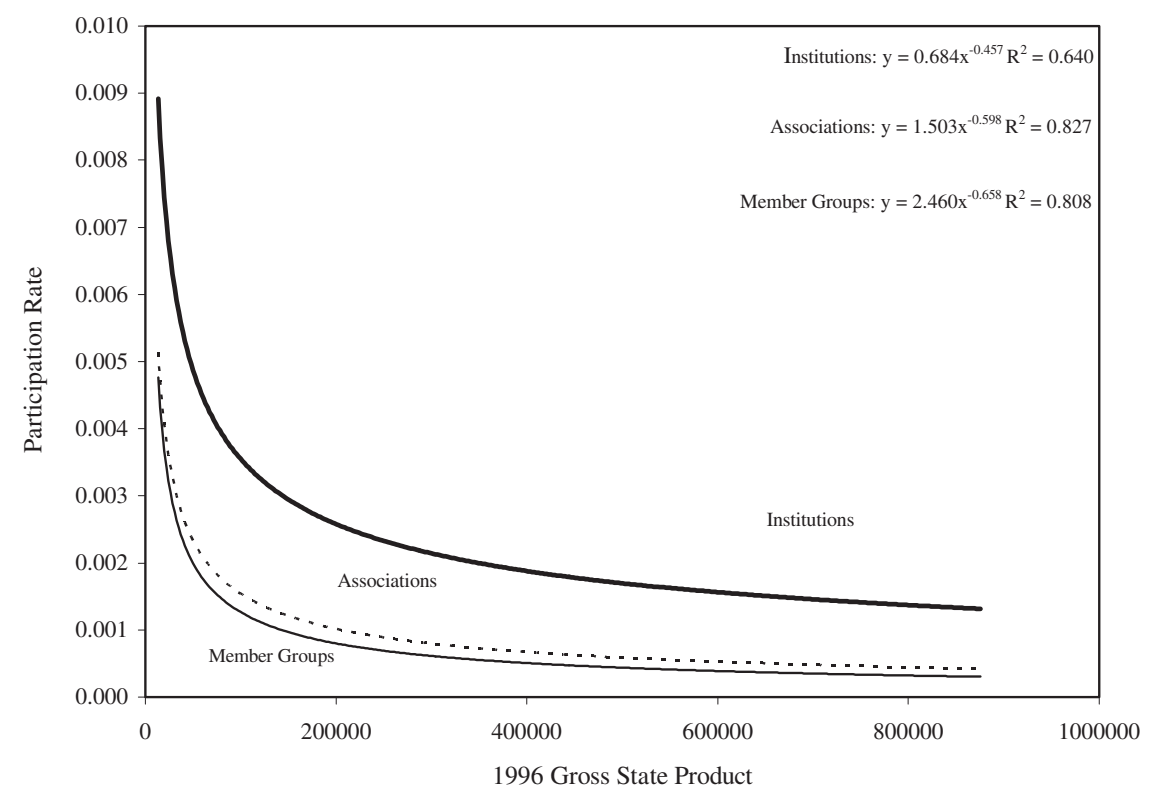

the economic size response paths of voluntary organizations. In short, those who have used Olson's analysis to explain bias in interest communities are wrong in two key respects. First, institutions engaged in direct lobbying are not immune to problems of collective action. And second, the severity of the collective action problems they face means that state size influences the population of institutions engaged in lobbying in much the same manner and degree as it affects the population of voluntary organizations engaged in lobbying.

\section{Conclusion}

Contrary to the tepid evidence of free riding in prior literature, we found very strong and consistent evidence across the seven sectors that problems of collective action influence participation rates in direct lobbying by institutions. Institutions are not immune to problems of collective action. And while the evidence presented in Figure 8 must be viewed more tentatively, the collective action problem facing populations of institutions that might lobby directly seems to render their responsiveness to state size quite similar to that of voluntary organizations. Importantly, while our findings challenge a standard explanation of bias 
in interest communities, they do not challenge Olson's analysis. Indeed, our findings suggest that Olson's analysis of the collective action problem is more broadly applicable than commonly allowed. But if free riding bears strongly on both voluntary organizations and institutions engaged in direct lobbying, then accounting for variations in the diversity or bias of interest communities may require much more than all too easy reference to Olson's view that some kinds of organizations are more severely burdened by problems of free riding than others. In all likelihood, such a new theory of bias in or the diversity of interest communities will entail the difficult task of determining how variations in the economies of scale of political organization, the heterogeneity of interests, and government involvement influence lobbying participation rates across the full range of organized interests seeking to influence government. Developing such a theory is beyond the scope of this paper, although significant elements of it have been developed recently (Gray, Lowery, and Wolak 2001; Lowery and Gray 1998b, 2001; Lowery, Gray, and Fellowes 2002). Rather, our major finding is that such a new theory is needed. Older theories of bias built on assumptions about differential rates of free riding are flawed.

Last, we offer three caveats. First, our results speak neither to the absolute degree of imbalance between voluntary and nonvoluntary organizations found in all interest communities nor the relative power of these different kinds of organizations. Bias in representation may well be real, especially so when weighted by profound differences in access to the resources used to influence public policy. Second, our results do not suggest that many of the factors found to be important in PAC studies are unimportant. These include firm size, firm and industry dependence on the policy process, interlocking directorates, and a number of other factors. All are likely important in explaining differences in participation across industries or firms. But controlling for these factors renders cross-industry tests of the collective action hypotheses very difficult. We have sidestepped these problems by employing a multistate, within-industry design. The use of this design, however, means that our results can tell us little about the role of other variables that surely matter in an institution's decision to seek influence. And third, it should be obvious that these results do not imply that larger states have fewer institutions engaged in lobbying. Even at lower rates, larger states still have so many more institutions that might engage in lobbying that they still generate larger registration rolls. Studies of the population density of communities of organized interests, however, require different models than those testing hypotheses framed at the level of the individual firm or citizen (Gray and Lowery 1996). ${ }^{10}$

\footnotetext{
${ }^{10}$ Still, this analysis bears on demographic analyses of interest communities in one key respect. Gray and Lowery (2001b) report that density dependence of interest communities results equally from higher birth and death rates of interests in larger states. Our findings suggest that, at least for direct institutional lobbying, lower birth rates in larger interest systems are likely due to free riding.
} 


\section{Acknowledgment}

An earlier version of this paper was presented at the Annual Meeting of the Midwest Political Science Association, Chicago, Illinois. This research is supported by the National Science Foundation (Grant SBR9709439), for which we are profoundly grateful.

Manuscript submitted October 16, 2002

Final manuscript received December 3, 2003

\section{References}

Andres, Gary J. 1985. "Business Involvement in Campaign Finance: Factors Influencing the Decision to Form a Corporate PAC.” PS 18(2): 156-81.

Baumgartner, Frank R., and Beth L. Leech. 1998. Basic Interests. Princeton: Princeton University Press.

Baumgartner, Frank R., and Beth L. Leech. 2001. "Interest Niches and Policy Bandwagons: Patterns of Interest Group Involvement in National Politics.” Journal of Politics 63(4): 1191-1213.

Berry, Jeffrey M. 1999. The New Liberalism. Washington: Brooking Institution Press.

Boies, John L. 1989. "Money, Business, and the State: Material Interests, Fortune 500 Corporations, and the Size of Political Action Committees." American Sociological Review 54(4): 821-33.

Caldeira, Gregory, and John R. Wright. 1990. "Amicae Curiae before the Supreme Court: Who Participates, When, and How Much?” Journal of Politics 52(3): 782-806.

Clark, Peter B., and James Q. Wilson. 1961. "Incentives Systems: A Theory of Organizations.” Administrative Science Quarterly 6(2): 129-66.

Denzau, Arthur T., and Michael C. Munger. 1986. "Legislators and Interest Groups: How Unorganized Interests Get Represented." American Political Science Review 80(1): 89-106.

Gais, Thomas. 1996. Improper Influence. Ann Arbor: University of Michigan Press.

Golden, Marissa Martino. 1998. "Interest Groups in the Rule-Making Process: Who Participates? Whose Values Get Heard?" Journal of Public Administration Research and Theory 8(2): 245-70.

Gray, Virginia, and David Lowery. 1996. The Population Ecology of Interest Representation. Ann Arbor, Michigan: University of Michigan Press.

Gray, Virginia, and David Lowery. 1997. "Reconceptualizing PAC Formation: It's Not a Collective Action Problem, and It May Be an Arms Race.” American Politics Quarterly 25(3): 319-46.

Gray, Virginia, and David Lowery. 1998. "State Lobbying Regulations and Their Enforcement: Implications for the Diversity of State Interest Communities." State and Local Government Review 30(2): 78-91.

Gray, Virginia, and David Lowery. 2001a. "The Institutionalization of State Communities of Organized Interests." Political Research Quarterly 54(2): 265-84.

Gray, Virginia, and David Lowery. 2001b. "The Expression of Density Dependence in State Communities of Organized Interests." American Politics Quarterly 29(4): 374-91.

Gray, Virginia, David Lowery, and Jenny Wolak. 2001. "Demographic Opportunities, Collective Action, Competitive Exclusion, and the Crowded Room: Lobbying Forms Among Institutions." Presented at the Annual Meeting of the Midwest Political Science Association.

Grier, Kevin B., Michael C. Munger, and Brian E. Roberts. 1991. "The Industrial Organization of Corporate Political Participation.” Southern Economic Journal 57(3): 727-38.

Grier, Kevin B., Michael C. Munger, and Brian E. Roberts. 1994. "The Determinants of Industry Political Activity, 1978-1986." American Political Science Review 88(4): 911-26.

Hansen, John Mark. 1985. "The Political Economy of Group Membership." American Political Science Review 79(1): 79-96. 
Hansen, Wendy L., and Neil J. Mitchell. 2000. "Disaggregating and Explaining Corporate Political Activity: Domestic and Foreign Corporation in National Politics." American Political Science Review 94(4): 891-903.

Hart, David M. 2001. "Why Do Some Firms Give? Why Do Some Give a Lot?: High-Tech PACs, 1977-1996." Journal of Politics 63(4): 1230-49.

Herndon, James F. 1982. "Access, Record, and Competition as Influences of Interest Group Contributions to Congressional Campaigns." Journal of Politics 44(4): 997-1019.

Humphries, Craig. 1991. "Corporations, PACs and the Strategic Link Between Contributions and Lobbying Activities.” Western Political Quarterly 44(2): 353-72.

Lowery, David, and Virginia Gray. 1994. "Do Lobbying Regulations Influence Lobbying Registrations?" Social Science Quarterly 75(2): 382-84.

Lowery, David, and Virginia Gray. 1995. "The Population Ecology of Gucci Gulch, or the Natural Regulation of Interest Group Numbers in the American States." American Journal of Political Science 39(1): 1-29.

Lowery, David, and Virginia Gray. 1997. "How Some Rules Just Don’t Matter: The Regulation of Lobbyists." Public Choice 91: 139-47.

Lowery, David, and Virginia Gray. 1998a. "The Dominance of Institutions in Interest Representation: A Test of Seven Explanations." American Journal of Political Science 42(1): 231-55.

Lowery, David, and Virginia Gray. 1998b. "Representational Concentration and Interest Community Size: A Population Ecology Interpretation.” Political Research Quarterly 51(4): 91944.

Lowery, David, and Virginia Gray. 2001. "Bias in the Heavenly Chorus: Interests in Society and Before Government." Presented at the Annual Meeting of the American Political Science Association, San Francisco, California.

Lowery, David, Virginia Gray, and Matthew Fellowes 2002. "Sisyphus Meets the Borg: Understanding the Diversity of Interest Communities." Paper presented at the Annual Meeting of the American Political Science Association, Boston, Massachusetts.

Marwell, Gerald, and Ruth E. Ames. 1979. "Experiments on the Provision of Public Goods. I. Resources, Interest, Group Size, and the Free Rider Problem." American Journal of Sociology 85(6): 1335-60.

Marwell, Gerald, and Ruth E. Ames. 1980. "Experiments on the Provision of Public Goods. II. Provision Points, Stakes, Experiences, and the Free Rider Problem." American Journal of Sociology 86(4): 926-37.

Masters, Marick F., and Gerald D. Keim. 1985. "Determinants of PAC Participation Among Large Corporations." Journal of Politics 47(4): 1158-73.

Matasar, Ann B. 1986. Corporate PACs and Federal Campaign Laws. New York: Quorum Books.

McKeown, Timothy. 1994. "The Epidemiology of Corporate PAC Formation, 1975-84." Journal of Economic Behavior and Organization 24(2): 153-68.

Mitchell, Neil J., Wendy L. Hansen, and Eric Jepsen. 1997. "The Determinants of Domestic and Foreign Corporate Political Activity.” Journal of Politics 59(4): 1096-72.

Moe, Terry M. 1980. The Organization of Interests. Chicago: University of Chicago Press.

Nownes, Anthony. 2001. Pressure and Power. Boston: Houghton Mifflin Company.

Olson, Mancur, Jr. 1963. The Logic of Collective Action. Cambridge: Harvard University Press.

Plotke, David. 1992. "The Political Mobilization of Business." In The Politics of Interests, ed. Mark P. Petracca. Boulder: Westview Press, pp. 175-200.

Rosenstone, Steven J., and John Mark Hansen. 1993. Mobilization, Participation, and Democracy in America. New York: Macmillan.

Sabato, Larry J. 1984. PAC Power. New York: Norton.

Salisbury, Robert. 1969. "An Exchange Theory of Interest Groups." Midwest Journal of Political Science 13(1): 1-32.

Salisbury, Robert. 1984. "Interest Representation: The Dominance of Institutions." American Political Science Review 81(1): 64-76. 
Salisbury, Robert. 1990. "The Paradox of Interest in Washington: More Groups, Less Clout.” In The New American Political System, 2nd ed., ed. Anthony S. King. Washington: American Enterprise Institute, pp. 203-30.

Schattschneider, E. E. 1960. The Semisovereign People. New York: Holt, Rinehart, and Winston.

Schlozman, Key Lehman. 1984. "What Accent the Heavenly Chorus? Political Equality and the American Pressure System.” Journal of Politics 46(84): 1006-32.

Schlozman, Kay Lehman, and John T. Tierney. 1986. Organized Interests and American Democracy. New York: Harper and Row.

Smith, Mark A. 2000. American Business and Political Power. Chicago: University of Chicago Press. Sorauf, Frank. J. 1984. What Price PACs? New York: Twentieth Century Fund.

Truman, David. 1951. The Governmental Process. New York: Alfred A. Knopf.

U.S. Department of Commerce. 2000. Statistical Abstract of the United States. Washington: U.S. Government Printing Office.

Verba, Sidney, Kay Lehman Schlozman, and Henry E. Brady. 1995. Voice and Equality. Cambridge: Harvard University Press.

Walker, Jack L., Jr. 1991. Mobilizing Interest Groups in America: Patrons, Professionals, and Social Movements. Ann Arbor: University of Michigan Press.

Wolak, Jennifer, Adam Newmark, Todd McNoldy, David Lowery, and Virginia Gray. 2002. "Much of Politics is Still Local: Multi-State Lobbying Before State Legislators.” Legislative Studies Quarterly 27(4): 527-56.

Wright, John R. 1989. "PAC Contributions, Lobbying, and Representation.” Journal of Politics 51(3): 713-29.

Wright, John R. 1990. “Contributions, Lobbying, and Committee Voting in the U.S. House." American Political Science Review 84(2): 417-38.

David Lowery is Thomas J. Pearsall Professor of Political Science, The University of North Carolina at Chapel Hill, Chapel Hill, NC 27599-3265 (dlowery@email.unc.edu). Virginia Gray is Robert Watson Winston Professor of Political Science, The University of North Carolina at Chapel Hill, Chapel Hill, NC 27599-3265 (vagray@email.unc.edu). Jennifer Anderson is Ph.D. candidate of political science, The University of North Carolina at Chapel Hill, Chapel Hill, NC 27599-3265 (Anders11@email.unc.edu). Adam J. Newmark is visiting assistant professor of political science, Wake Forest University, Winston-Salem, NC 27599 (newmaraj@wfu.edu). 